\title{
The Utilization of Foreign Workers in Hospital in Terms of Law Number 11 Of 2020 Concerning Job Creation Law (Omnibus Law)
}

\author{
Wildan Sani \\ Doctoral of Law, Universitas Borobudur Jakarta \\ \{wildanunbor@gmail.com\}
}

\begin{abstract}
Job Creation Law or Omnibus Law proposes to create jobs and increase foreign investment in the country by reducing regulatory requirements for business licenses. This Omnibus Law has amended, deleted, or stipulated new regulations for several laws including several provisions stipulated in Law Number 13 of 2003 concerning Manpower. One of the amended provisions in the provision that regulates the utilization of foreign workers or hereinafter referred to as TKA is contained in the Manpower Law which is amended in the Job Creation Law. The amendment of these provisions is a form of simplification and convenience for foreign workers who want and will work in Indonesia. Under the context of this research is the utilization of foreign workers as health workers for foreign citizens or TK-FOREIGNERS who work in hospitals in Indonesia. The provisions governing foreign workers have been regulated in Law Number 13 of 2003 concerning Manpower. Meanwhile, what regulates foreign national health workers is regulated in Law Number 29 of 2004 concerning Medical Practice, Law Number 44 of 2009 concerning Hospitals, Government Regulation Number 67 of 2019 concerning Management of Health Workers. This study aims to determine the utilization of foreign workers in hospitals in terms of Law Number 11 of 2020 concerning Job Creation. This research is normative legal research using a statutory and conceptual approach.
\end{abstract}

Keywords: utilization; foreign workers; hospital; Omnibus Law

\section{Preliminary}

ASEAN Free Trade Area (AFTA) has been in force during the time, which is an agreement by ASEAN regarding the local production sector in all ASEAN countries and the ASEAN Economic Community (AEC) or Masyarakat Komunitas ASEAN (MEA). AEC is a form of the regional economic integration of ASEAN countries. The main objective of the AEC is to make ASEAN a single market and production base, where there is a free flow of goods, services, investment, and skilled labor and a freer flow of capital. ASEAN is expected to be a stable, prosperous, and competitive region with equitable economic development, reduced poverty, and a diverse socio-economy. 
The AFTA and MEA policies also apply to the utilization of health services for foreign nationals or TK-FOREIGNERS. Indonesia as an ASEAN country inevitably has to follow these rules in the framework of regional cooperation of the countries that are members of ASEAN.

Besides, the situation in the development of world economic globalization and the Industrial Revolution 4.0 has continued to pressure Indonesia to immediately improve the labor market by reforming labor regulations. Regulatory reform is proposed at ensuring that these regulations are fully responsive to changing economic, social, and technical conditions that surround them. At the same time, regulatory reform is a powerful stimulus for innovation. [1] Regulatory reform is needed to face increasingly competitive global competition.

In 2019, the government has launched the Omnibus Law program, which is a method used to replace and/or revoke provisions in a Law, or to rearrange several provisions in a Law into one (Thematic) Law. [2] In Maria Farida Indrati's perspective, omnibus (Latin) means for all or everything. Of course, the term omnibus law means law for all or everything. According to Maria, from the various formulations of the meaning of omnibus, the understanding of one (new) law which contains or regulates various kinds of substances and subjects to simplify several laws that are still in force. [3] The Omnibus Law program is known as the Job Creation Bill.

Then the Job Creation Bill was passed into Law Number 11 of 2020 concerning Job Creation or hereinafter referred to as the Job Creation Law on October 5, 2020, by the Indonesian Parliament and enacted on November 2, 2020, intending to create jobs and increase foreign investment in the country by reducing the regulatory requirements for business licenses. Because it is 1,187 pages long and covers many sectors, this law is also known as the broom law. Thus, this broomstick rule is starting to officially apply in Indonesia, including those that regulate employment.

One of the concerns regarding the existence of the Job Creation Law is the regulation that makes it easier for foreign workers to operate and work in Indonesia. This Job Creation Law has changed, deleted, or stipulated new regulations for several provisions stipulated in Law Number 13 of 2003 concerning Manpower or hereinafter referred to as the Manpower Law. However, the amendments, the elimination of articles that were originally contained in the Manpower Law, and the stipulation of new regulations in the Job Creation Law have caused controversy in the community and received many rejections from various parties because they are considered to have disadvantaged workers or workers of Indonesian citizens themselves.

One of the amended provisions in the provision that regulates the utilization of foreign workers or hereinafter referred to as TKA is contained in the Manpower Law which is amended in the Job Creation Law. The amendment of these provisions is a form of simplification and convenience for foreign workers who want and will work in Indonesia. TKA in the broad sense of foreign workers who work in all sectors. Following the context of this research is the utilization of foreign workers as health workers for foreign citizens or TKFOREIGNERS who work in Indonesian hospitals. Based on the above background, then the adoption of TKA in the hospital under review from the Copyright Act is important. It is important to study more focused and in-depth from a legal perspective both the Labor Law and related to the current TKA and TK-FOREIGNERS stipulations.

\section{Research Problem}


Based on the background described above, the formulation of this research problem can be formulated as follows: How is the utilization of foreign workers in hospitals in terms of Law Number 11 of 2020 concerning Job Creation Law?

\section{Research Method}

This research is normative legal research. Normative research is often called doctrinal research, which is research whose object of study is legal documents and library materials.[4] Bahder Johan Nasution stated that normative legal research is in the form of an inventory of applicable laws, seeking to find principles or philosophical basis of these laws, or research in the form of legal discovery efforts that are suitable for a particular case.[5]

\section{Discussion}

According to Article 1 number 2 Law no. 13 of 2003, what is meant by manpower is any person who able to do work to produce goods and/or services either to fulfill their own needs or for the community. Meanwhile, what is implied by foreign workers are foreign citizens who hold visas intending to work in the territory of Indonesia. [6] According to Abdul Hakim, a foreign worker is any person who is not an Indonesian citizen who can do work, both within and outside of a working relationship, to produce services or goods to meet the needs of the community. [7] According to Budiono, there are several objectives for the empowerment of foreign workers in Indonesia, namely: [8]

a. Fulfilling the need for skilled and professional workers in certain fields that cannot be filled by Indonesian Migrant Workers.

b. Accelerating the national development process by accelerating the process of transferring technology or transfer of knowledge, especially in the industrial sector.

c. Providing expansion of employment opportunities for TKI.

d. Increase foreign investment to support development capital in Indonesia.

In connection with the utilization of foreign workers and attracting investment from abroad, several regulations relating to the empowerment of foreign workers contained in the Manpower Law have been amended in the Job Creation Law. Previously, the rules regarding the use of foreign workers were regulated in Article 42 to Article 49 of the Manpower Law. In the Job Creation Law, this rule is amended in Article 81. The change is a form of simplification of permits for foreign workers who will work in Indonesia. The rules that are directly related to the utilization of foreign workers are Article 42 concerning employment in the Job Creation Law. In full, the sound of Article 42 on employment in the Job Creation Act reads:

a. Every employer who employs foreign labor must have a plan for the use of foreign labor approved by the Central Government.

b. Individual employers are prohibited from employing foreign labor.

c. The provisions as referred to in paragraph (1) do not apply to: (1) directors or commissioners with certain share ownership or shareholders under the provisions of laws and regulations; (2) diplomatic and consular staff at representative offices of foreign countries; or (3) foreign workers required by employers in types of production activities that have stopped due to emergencies, vocations, technology-based start-ups, business visits, and research for a certain period. 
d. Foreign workers can be employed in Indonesia only in a working relationship for a certain position and for a certain time and have the competence according to the position to be occupied.

e. Foreign workers are prohibited from occupying positions in charge of personnel.

f. Provisions regarding certain positions and certain times as referred to in paragraph (4) shall be regulated in a Government Regulation.

Article 42 of the Job Creation Law has amended Article 42 paragraph (1) of the Manpower Law, where previously the provisions of Article 42 paragraph (1) in the Manpower Law stated "Every employer who employs foreign workers is required to have a written permit from the Minister or an appointed official". In connection with this, it has also been regulated in Presidential Regulation Number 20 of 2018, including Stay Visa, Limited (Vitas), Planned Use of Foreign Workers, and Permits to Use Foreign Workers. However, this provision is amended in the Job Creation Law, so that companies sponsoring foreign workers only need to have a TKA Utilization Plan (RPTKA).

In Article 42 paragraph (3) of the Manpower Law, written permission is made easier only for diplomatic and consular employees. However, in the Job Creation Law, this is expanded. Not only does not need to obtain written permission, but there are also even several positions that do not need to have an RPTKA, such as directors, commissioners, or shareholders, as well as foreign workers required by employers in types of production activities that have stopped due to emergencies, vocations, startups based on technology, business visits, and research for a certain period.

The article that regulates the details of RPTKA in the Manpower Law, namely Article 43 has been deleted in the Job Creation Law. Article 43 of the Manpower Law states that the information that needs to be stated includes, among other things, the reasons for the use of the TKA, the status or position of the TKA in the company structure, the working period, and the appointment of an Indonesian TKA as a companion.

The provisions of Article 42 paragraph (5) stipulated that foreign workers are prohibited from occupying positions in charge of personnel. Previously, this provision was in Article 46 of the Manpower Law. With the paragraph, Article 46 of the Manpower Law is deleted in the Job Creation Law. Besides, the stipulations regarding positions and competency standards that were originally stated in Article 44 of the Manpower Law in the Job Creation Law were deleted, because this provision was included in Article 42 paragraph (4) of the Job Creation Law.

The Job Creation Law has removed the requirement for companies to repatriate foreign workers, which was previously stated in Article 48 of the Manpower Law. The content of the regulation: "Employers who employ foreign workers are obliged to return the foreign workers to their country of origin after their employment relationship ends". This rule was removed in the Job Creation Law.

Based on the provisions governing the TKA in the Work Copyright Act, then the TKA can work in Indonesia as long as it meets the requirements as determined in the Work Copyright Law. This provision also applies to TKA to work in both government hospitals and private hospitals under the provisions of the law.

It should be noted that TKA working in hospitals can be distinguished as non-health worker TKA working in hospital management or referred to as utilization of Foreign Citizen Health Human Resources in the managerial field in health service facilities, and TKA as health workers who work in health service facilities or hospital. Hospital is a health service institution that performs complete individual health services that provide inpatient, outpatient, and emergency services. [9] 
A health worker is any person who will devote himself/herself to the health sector and possess the knowledge and/or skills through education in the health sector which for certain types requires the authority to carry out health efforts. [10] Health workers are divided into several groups and sub-groups, namely medical personnel, clinical psychologists, nursing staff, midwifery workers, pharmaceutical workers, public health workers, environmental health workers, nutrition workers, physical technicians, medical technicians, biomedical engineering personnel, traditional health workers, and other health workers. [11]

Meanwhile, Foreign Citizen Health Workers, hereinafter abbreviated as TK-WNA, are foreign citizens who have the knowledge and/or skills through education in the health sector recognized by the Government. [12] At this time the general provisions governing the utilization of TK-FOREIGNERS who work in hospitals as health service facilities are contained in Law Number 44 of 2009 concerning Hospitals, Article 14 which reads:

a. Hospitals can employ foreign health workers according to the need for services.

b. The utilization of foreign health workers as referred to in paragraph (1) shall only be carried out by taking into account the interests of technology and knowledge transfer as well as the availability of local health personnel.

c. The utilization of foreign health workers as referred to in paragraph (1) shall only be carried out for foreign health workers who already have a Registration Certificate and Practice License.

d. Further provisions regarding the utilization of foreign health workers in paragraph (1) paragraph (2) and paragraph (3) shall be regulated by a Government Regulation.

Meanwhile, the regulation regarding foreign doctor or dentist working in Indonesia is regulated in Law Number 29 of 2004 concerning Medical Practice, which is contained in Article 30 paragraph (2) which reads: "Doctors and dentists are foreign nationals in addition to fulfilling the provisions referred to in paragraph (2). (2) must also complete a work permit under the provisions of laws and regulations and the ability to speak Indonesian".

Furthermore, it is stated in Article 32 of the same law that a certificate of conditional registration is given to participants of the education program for specialist doctors or dentists who are foreign nationals who have attended education and training in Indonesia. Meanwhile, doctors or dentists who are foreign nationals who will provide education and training in the context of transferring science and technology for a certain period do not need a conditional registration certificate. The doctor or dentist who is a foreign citizen as intended must obtain approval from the Indonesian Medical Council (KKI). Besides, it is regulated in Government Regulation Number 67 of 2019 concerning Management of Health Workers, namely in Article 58 which reads:

a. TK-FOREIGNER utilization can be carried out by Health Service Facilities belonging to the central government, regional governments, and individuals following the requirements based on the provisions in this Government Regulation and the provisions of the related laws and regulations.

b. TK-FOREIGNER utilization shall be carried out by taking into account: (1) transfer of knowledge, skills, and technology; and (2) availability of Indonesian citizen Health Workers.

c. TK-FOREIGNER can only be utilized:

1. if the competency owned by the Foreign Worker has not been owned by Indonesian citizen Health Workers and/or has been owned by a small number of Indonesian citizen Health Workers;

2. by using companion Health Workers;

3. after receiving a recommendation from the Minister; and 
4. if the TKWNA concerned comes from a country that has diplomatic relations with the Republic of Indonesia.

d. In addition to health service activities, Foreign Worker utilization can be implemented in other fields under the provisions of laws and regulations.

Meanwhile, the specific stipulations governing the utilization of Foreign Worker have been regulated in the Regulation of the Minister of Health of the Republic of Indonesia Number 67 of 2013 concerning the Empowerment of Foreign Citizen Health Workers. The regulation governs the requirements and procedures for utilizing health workers of foreign nationals in the corridor of transfer of science and technology for 4 activity fields, namely health services, health education and training, health social services, and health research. In terms of the utilization of managerial field of health human resources for foreigners in health service facilities, the Head of the PPSDM Health Agency Regulation Number HK.01.07 / I.2 / 012151/2015 concerning the Utilization of Managerial Health Human Resources for Foreign Citizens in Health Service Facilities has been drafted.

Permenkes No. 67/2013 states that Foreign Worker's users hereinafter referred to as users are institutions, companies, or organizations that are legal entities and already have permission to use Foreign Workers to carry out health efforts by paying wages or other forms of compensation. [13] Most of them are private hospitals that serve as Foreign Worker assistants who are legally incorporated organizations. Where in the utilization of Foreign Workers must have RPTKA, namely plans to use Foreign Workers in certain positions made by Users for a certain period. [14] This is as stipulated in the Job Creation Law which states that the utilization of foreign workers is only sufficient with RPTKA. Even a certain number of positions do not need to have RPTKA, such as Directors, Commissioners, or Shareholders. This also applies to the position of Directors, Commissioners, or shareholders of private hospitals in Indonesia as non-health worker TKA. It means that non-health worker TKA can hold the position of Directors or Commissioners in a private hospital in Indonesia.

It should be noted that the TK-Foreigners utilization can be carried out as long as there is a bilateral cooperation between the Republic of Indonesia and the country of origin of the TTKForeigners. [15] This means that the utilization of Foreign Workers only applies to foreign countries having bilateral relations with the Indonesian state, for example, the country of doctors or other health workers from China as TK-FOREIGNERS can work in Indonesia, because they already have bilateral relations between the two countries. Besides, it cannot be applied to countries that do not have bilateral relations with the Indonesian state, for example, a doctor from the state of Israel cannot work as a TK-Foreigners in Indonesia, because Indonesia does not have bilateral associations with Israel.

TK-FOREIGNERS utilization activities include: a. health services; $b$. health education and training; c. social service in the health sector; and D. health research. [16] Types of TKWNA that can be utilized include doctors, dentists, and other health workers. [17]

Utilization of TK-FOREIGNERS in health service activities is the provision of direct or indirect health services to patients/clients in User health service facilities. The TKFOREIGNERS utilization in the intended health service activities must be carried out using a companion. [18] Assistants are Indonesian health workers who receive technology transfer from the TK-FOREIGNERS and have a minimum competency equivalent to the TKFOREIGNERS and are responsible for the technology transfer process. [19] The companion must be able to absorb and take advantage of the knowledge and technology mastered/possessed by the Foreign Workers. [20]

The provisions concerning TKA contained in the Job Creation Law are general for TKA. Until now there has been no Government Regulation governing foreign workers which is a 
derivative of the Job Creation Law. Likewise, there are no specific regulations derived from the Job Creation Law that regulate TK-FOREIGNERS. As long as there are no derivative regulations, the regulations regarding TK-FOREIGNERS still refer to the old stipulations.

One thing to remember is that bringing in foreign doctors to Indonesia to work in hospitals is not as simple and easy as we imagine, such as bringing in foreign workers (TKA) to work in the mining sector, toll projects, fast trains, or in other megaprojects. Although the existing regulations in the era of the ASEAN Economic Community (AEC) and the AFTA (ASEAN Free Trade Area) agreement, the presence of foreign doctors to practice in Indonesia is very possible, as long as they follow the applicable regulations. Providing easy entry permits and granting visas to foreign doctors will certainly not be difficult.

However, this is not the case if a doctor as a TK-FOREIGNERS will practice legally in Indonesia, regardless of the type of expertise or specialization. Recognition/recognition of the competence and expertise of a doctor as a TKWNA must first be done by the Indonesian Medical Council (KKI) by registering the doctor as a TKWNA before obtaining a license to practice. The same provisions also apply to Indonesian doctors.

Recognition/recognition of qualifications and license to practice for "foreign doctors" who will practice in Indonesia is very important. That is because the duty of a doctor with competence according to his / her field of expertise must ensure patient safety, which ultimately involves the safety of human life. There are at least 3 regulations related to this, namely Government Regulation Number 67 of 2019 concerning Management of Health Workers, Regulation of the Medical Council (Perkonsil) Number 17 of 2013 concerning Temporary Registration and Conditional Registration of Foreign Doctors Who Will Work in Indonesia, funds of Ministerial Regulations Health (PMK) Number 67 of 2013 concerning the Empowerment of Foreign Health Workers, among other things, contains the provision that only foreign specialists or subspecialists are given opportunities, whose qualifications do not exist or are indeed rare in Indonesia.

Based on the discussion above, in general, terms related to the policy on the ease of foreign workers to work in Indonesia as regulated in the Job Creation Law in general, it is considered to have more harm than good. It stands to reason that Article 42 is the result of amendments, namely Article 42 paragraph (3) letter $c$. Article 42 paragraph (3) letter $c$ does not regulate the definition and limitation or criteria for emergencies, vocations, start-ups, business visits, and research, which will result in increasingly narrow and closed employment opportunities for Indonesian citizens.[21] There is also the potential for misuse of foreign workers working in Indonesia freely without a Plan for the Use of Foreign Workers (RPTKA) or permission from the government.

The provisions of Article 42 in the Job Creation Law have implications, first, the ease with which foreign workers can enter Indonesia to work in Indonesia and have the potential to take employment opportunities from domestic workers. Second, the difficulty in monitoring and producing accurate data on the number of foreign workers who enter and work in Indonesia. Third, the ratification of the plan to use foreign workers is exempted for several foreign workers in several types of work. [22]

This norm is considered contrary to Article 27 paragraph (2) of the 1945 Constitution which states that every Indonesian citizen has the right to work and a decent living for humanity. With this facility, every foreign worker has the right to a decent job and livelihood in Indonesia. Likewise, policies related to the convenience for foreign doctors as foreign workers will be carried out by giving them special visas so that the administrative processes needed to enter Indonesia can be easier, so Indonesia will be flooded with foreign workers including TK-foreigners. 
Especially if there will be more TKWNA who work in hospitals, especially private ones, it will harm the Indonesian citizen workforce. Even though the Job Creation Law is intended to open the widest possible job opportunities. However, the simplification of permits for foreign workers to work in Indonesia is contrary to the objectives of the Job Creation Law itself, which means opening up jobs for foreign workers.

In particular, the regulation on the convenience of foreign doctors as foreign workers to work in hospitals in Indonesia has been criticized by Indonesian medical students abroad. They argue that it is still difficult for Indonesian doctors with foreign graduates to work in their own country. They expressed their objections to the discourse about the ease of licensing for foreign doctors. How can foreign doctors be made easier, while Indonesian who possess foreign graduates should fight hard to be able to practice in Indonesia. [23]

Regulation of the Indonesian Medical Council Number 41 of 2016 concerning the Implementation of the Adaptation Program for Indonesian Citizens and Dentists for Overseas Graduates states that Indonesian graduates from abroad must start the process of equalizing their diplomas at the Ministry of Education and Culture. Furthermore, the foreign medical graduates must carry out administrative processes at the Indonesian Medical Council (KKI), the Indonesian Medical College Council (MKKI), and the Indonesian Doctors Association (IDI). After going through a series of administrative processes, foreign graduates are required to take a placement test by first having to obtain a cover letter from universities in Indonesia to participate in the adaptation process. The time required for the adaptation process in Indonesian tertiary institutions takes a maximum of a year for general practitioners who have graduated abroad, while for specialist doctors a maximum of two years. [24]

The duration of the adaptation also depends on regulations from the campus in Indonesia and the costs of the adaptation program are borne by the graduates themselves. The process of implementing this adaptation, which is quite long and not simple, has resulted in many foreign graduate doctors thinking twice before deciding to practice and work in Indonesia.

Perluni, as an autonomous body under the Indonesian Student Association in China (PPIT), asked the Indonesian government to care about this phenomenon by empowering Indonesian graduate doctors from abroad. Perluni stated that many Indonesian doctors also excel abroad and want to serve the nation and state.

Minister of Research, Technology and Higher Education for the 2014-2019 period, M. Nasir, in his visit to the Indonesian Embassy in Beijing in 2018, revealed that many Chinesegraduated Indonesian doctors have practiced in Singapore and Malaysia because they are not accommodated in their own country. Ironically, their patients also come from Indonesia. According to him, many of our doctors have practiced as specialist doctors abroad. They want to return to Indonesia to serve but are constrained by various adaptation processes and the bureaucracy in Indonesia that take a very long time. [25]

Adib Khumaedi, the elected chairperson of PB IDI, suggested making a thorough improvement in advance of the problem of the distribution of doctors, which number has reached around 180 thousand people, who have been experiencing problems with placement (maldistribution) that have not been resolved. This problem needs to be immediately addressed because there are many people in peripheral and remote areas as well as in border areas who lack doctors and other health workers. They have long longed for the presence of Indonesian doctors, not "foreign doctors". [26]

Likewise, improving the quality of health services at hospitals and health centers should be a top priority. On the other hand, the agreed group said that the presence of foreign doctors with certain expertise would encourage the improvement of the skills and knowledge of Indonesian doctors. That is because it is expected that there will be a 'transfer of knowledge 
and skills in the medical field which is ultimately very useful in public health services. This means that the presence of foreign doctors with certain expertise is an opportunity for Indonesian doctors to advance knowledge, skills, and expertise in medical technology. Both opinions are rational.

At first glance, the presence of foreign doctors with certain qualifications seems quite attractive and promising, especially for well-off patients. That is because the health services provided are expected to be very good in an international standard hospital even though it must be "high cost". However, the presence of foreign doctors as health workers can only be experienced by a few people, and cannot be enjoyed by the majority of the Indonesian people, who number nearly 300 million people.

\section{Conclusion and Suggestion}

\section{1 Conclusion}

The utilization of foreign workers as stipulated in the Job Creation Law is more detrimental to the Indonesian people than beneficial. The regulation of foreign workers in the Job Creation Law contradicts the constitution which states that providing a decent living for humanity is a state obligation, not providing a decent living for foreign workers. Besides, the ease of utilizing foreign workers in the Job Creation Law will be detrimental to prospective health workers who will work, because they are marginalized by TKWNA imported from outside, thus creating unemployment for Indonesian citizen health workers including medical personnel, clinical psychologists, nursing staff. , midwifery workers, pharmacy workers, community health workers, environmental health workers, nutrition workers, physical health workers, medical technical workers, biomedical engineering workers, traditional health workers, and other health workers.

\subsection{Suggestion}

The government should make it easier and simplify licensing for foreign graduate Indonesian doctors who wish to work in the country, instead of making it difficult for citizens of their nation who wish to devote themselves to the advancement of Indonesia. Not the other way around, it opens the way for foreign workers to work in Indonesia which is only 'profit oriented' and only enjoyed by certain groups or groups of people. It is better if the provisions regulating the ease of foreign workers in the Job Creation Law are revised again. One way to do this is by way of a judicial review of the Job Creation Law to the Constitutional Court. It is hoped that through this judicial review the Constitutional Court can accept the petition and grant it by canceling Article 42 of the Job Creation Law which regulates foreign workers.

\section{References}

[1] OECD.: Regulatory Form and Innovation. Retrieved from https://www.oecd. org/sti/inno/2102514.pdf

[2] Kementerian Koordinator Bidang Perekonomian Republik Indonesia.: Penjelasan Omnibus Law Cipta Lapangan Kerja. Jakarta (19 Januari 2020). 
[3] Indrati, Maria Farida: Omnibus Law, Demokrasi, dan Otonomi Daerah. Article. Retrieved from https://nasional.kompas.com/read/2020/03/02/09461161/omnibus-lawdemokrasi-danotonomi-daerah?page $=$ all\#page 4

[4] Soejono dan H. Abdurahman.: Metode Penelitian Hukum. Rineka Cipta Jakarta (2003).

[5] Nasution, Bahder Johan.: Metode Penelitian Ilmu Hukum. Mandar Maju, Bandung (2008).

[6] Undang-Undang Republik Indonesia Nomor 13 Tahun 2003 tentang Ketenagakerjaan.

[7] Hakim, Abdul.: Dasar-Dasar Hukum Ketenagakerjaan Indonesia. Citra Aditya Bakti, Bandung (2009)

[8] Budiono, Abdul Rachmat.: Hukum Perburuhan Di Indonesia. Rajagrafindo Persada, Jakarta (1995)

[9] Undang-Undang Republik Indonesia Nomor 44 Tahun 2009 tentang Rumah Sakit.

[10][11] Undang-Undang Republik Indonesia Nomor 36 Tahun 2014 tentang Tenaga Kesehatan.

[12][13][14][15][16][17][18][19][20]Peraturan Menteri Kesehatan Republik Indonesia Nomor 67 Tahun 2013 tentang Pendayagunaan Tenaga Kesehatan Warga Negara Asing.

[21] Ringkasan Permohonan Perkara Nomor 103/PUU-XVIII/2020, Pengujian Formil Undang-Undang Cipta Kerja dan Konstitusionalitas Pengaturan Ketenagakerjaan Dalam Undang-Undang Cipta Kerja.

[22] Ringkasan Perbaikan Permohonan Perkara Nomor 105/PUU-XVIII/2020, Pengujian Formil Undang-Undang Cipta Kerja dan Konstitusionalitas Pengaturan Ketenagakerjaan Dalam Undang-Undang Cipta Kerja

[23] [24] [25] Adi Putra Korompis (Ketua Perluni).: Soal Dokter Asing, Mahasiswa Kedokteran Indonesia di China Protes Luhut. Article. Retrieved from https://kabar24.bisnis.com/read/20200929/15/1297913/soal-dokter-asing-mahasiswakedokteran-indonesia-di-china-protes-luhut. 29 September 2020.

[26] Khumaedi, Adib.: Dokter Asing Untuk Siapa?. Article. Retrieved from https://mediaindonesia.com/kolom-pakar/346404/dokter-asing-untuk-siapa,

[27] Peraturan Pemerintah Republik Indonesia Nomor 67 Tahun 2019 tentang Pengelolaan Tenaga Kesehatan.

[28] Peraturan Kepala Badan PPSDM Kesehatan Nomor HK.01.07/I.2/012151/2015 tentang Pendayagunaan Sumber Daya Manusia Kesehatan Warga Negara Asing Bidang Manajerial di Fasilitas Pelayanan Kesehatan. 